\title{
A Method of Determining Utilization for Wet Mountain Meadows on the Summit Allotment, Sequoia National Forest, California
}

\section{NEIL K. McDOUGALD AND RICHARD C. PLATT}

Highlight: Height-weight data were systematically collected to provide a basis for determining utilization for wet mountain meadows occurring on the Summit Allotment of the Sequoia National Forest. Comparison of utilization measurements using the height-weight tables generated from the data with measurements using the current grazed plot method of the California Region, Forest Service, U.S. Department of Agriculture, showed the inadequacy of using the present grazed plot method to determine utilization and percentage of allowed use on that allotment. New standards were devised which allow for more accurate determination of utilization and percentage of allowed use, which will thus allow these mountain meadows to be more effectively managed.

In order to attain proper grazing use in mountain meadows, the Forest Service, U.S. Department of Agriculture stated that each national forest region should establish allowable use standards to fit its needs. Allowable use is the maximum

Authors are resource officer and assistant resource ofticer, U.S. Forest Service, Sequoia National Forest, Hot Springs Ranger District, California Hot Springs, 93207.

Manuscript received May 7, 1975. average amount of current plant growth which can be removed from each species when the range is being maintained in satisfactory condition, or when the trend is upward (U.S. Dep. Agr. , Forest Serv., 1968). From the findings of various studies, the California Region (R-5) established allowed use standards which involve a grazed plot method for determining utilization in mountain meadows. A grazed plot is defined as one in which $85 \%$ of the leaves and flower stalks of the key species or group of key species are grazed to a height of 3 inches or less. An allowed use factor is a predetermined number of grazed plots out of 100 when allowed use, or desired utilization, is reached according to range condition. In this way, the grazed plot method incorporates range condition constraints which recognize forage production differential associated with condition, as well as regulate range utilization and bring about improvement in range condition. Therefore, meadows with a condition rating of very poor have allowed use factor values between 25 and 31 ; poor condition meadows, 32 to 40 ; fair condition meadows, 42 to 60; good condition meadows, 63 to 72 ; and excellent condition meadows, 74 to 75 . The allowed use factor always provides for at least $25 \%$ of the plots to remain at a stubble 
height of more than 3 inches to maintain condition. To determine percentage of allowed use, the number of grazed plots out of 100 is compared against the applicable allowed use factor.

The grazed plot method developed by the California Region (U.S. Dep. Agr., Forest Serv., 1969) is similar to the grazed plant method tested by Roach (1950); Hurd and Kissinger (1953); Mattox (1955); Springfield (1959, 1961); Springfield and Peterson (1964); Gierisch (1967); and Charlton (1968). These studies have shown the grazed plant method to be of value in determining utilization because it is rapid, easy to use and reasonably accurate. In the method, percentage of grazed plants is related to percent utilization. This utilization, or percentage of weight removed, is determined from stubble heights using height-weight charts for individual species.

Allowed use factors have been established for both wet and dry meadows, but not for specific species, and relate to a single standard stubble height. The Region-wide use of the single stubble height does not allow for important variations between sites. Ratliff (unpublished, Pacific Southwest Forest and Range Exp. Sta., Fresno, Calif.) suggested 16 types of meadows in the central Sierra, seven of which were classed as perennially wet meadows. Each meadow type was characterized by a different key species and soil combination. The single stubble height also does not allow for plants whose height would never exceed 3 inches or for plants which have been grazed but still exceed 3 inches in height.

Therefore, the objective of the study reported in this paper was to establish a method of more accurately determining utilization levels for wet mountain meadows by developing height-weight charts for individual species. These charts would allow for more accurate determination of utilization and percentage of allowed use, thus providing necessary data for future determination of allowed use standards for local conditions.

\section{Methods}

Data for the study were collected from three randomly selected wet meadows on the Summit Allotment in the Hot Springs District of the Sequoia National Forest. The meadows (Packsaddle, Nobe Young, and Redwood) are along the western divide of the southern Sierra Nevadas at an average elevation of $6,000 \mathrm{ft}$. The plant communities of the meadows are composed primarily of grasslike species and are watered by seeps or springs. A review of current toe-point analysis information revealed that $58 \%$ of all primary and secondary species occurring in the wet mountain meadows of the Sequoia National Forest were sedges (Carex spp.). Therefore, key sedge species occurring on the Summit Allotment were selected to determine the grazed plot definition.

Mature plants of smoothbeak sedge (Carex integra) and slenderbeak sedge (Carex athrostachya) were systematically sampled in 1969, 1970, and 1971. Smoothbeak sedge was sampled at Nobe Young Meadow and slenderbeak sedge at Packsaddle Meadow. Each year, 30 samples of each species were collected. In 1973, mature plants of ovalhead sedge (Carex festivella) and Nebraska sedge (Carex nebraskensis) were systematically sampled in Redwood Meadow; 15 samples of each species were taken. Time of clipping was early September in all years. Distinguishing individual plants was complicated by the sod-forming characteristics of the species. However, every effort was made to obtain the entire plant, including both the leaves and flower culms. A string was wrapped spirally around the plant from the base upward and the herbage clipped off at the soil surface. The entire plant was then cut into 1 -inch segments from the base upward and oven dried to a constant temperature of $68^{\circ} \mathrm{C}$ for 24

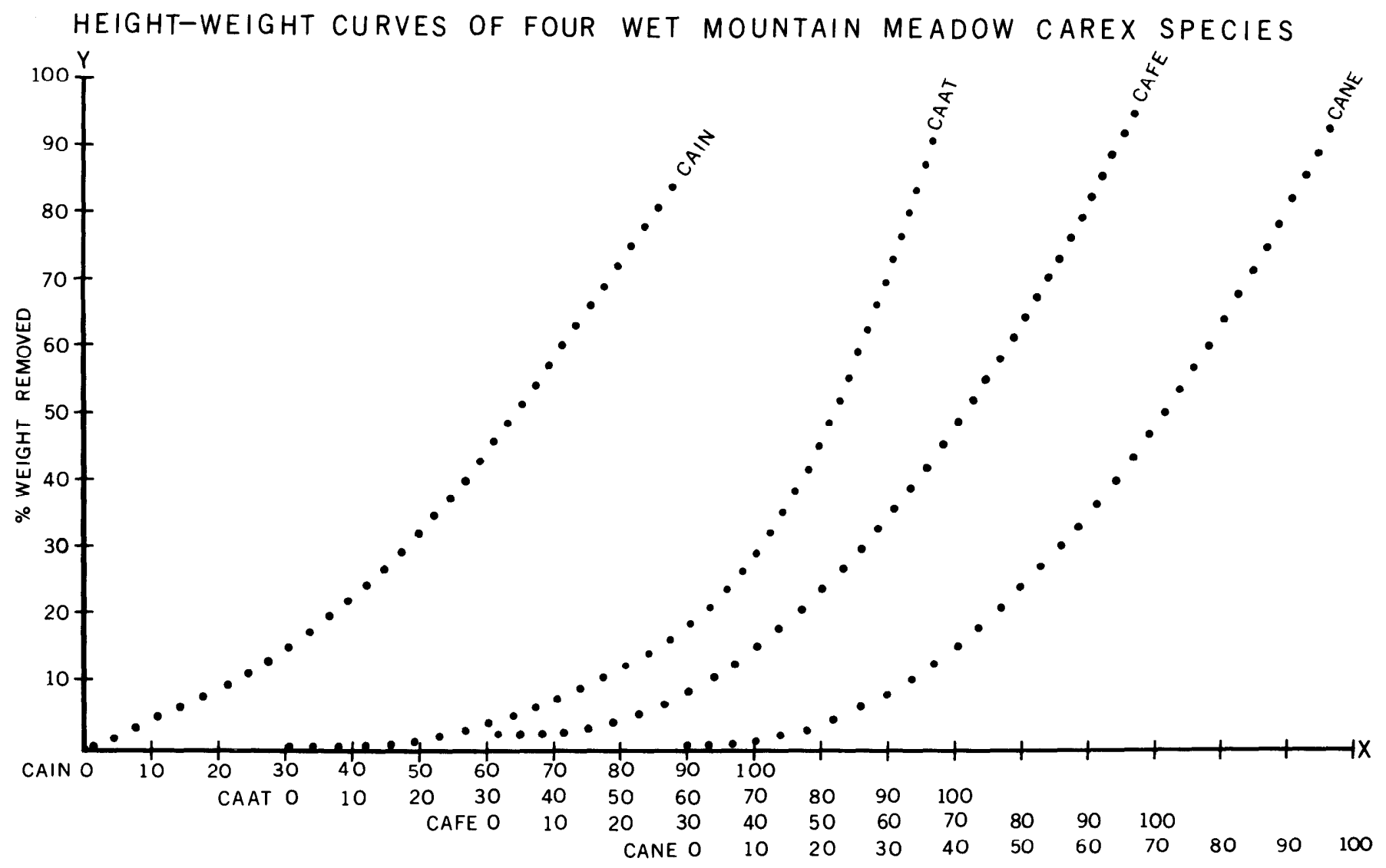

Fig. 1. Height-weight curves of four species of sedges occurring in wet mountain meadows on the Summit Allotment, Sequoia National Forest. Species symbols are: $C A I N=$ Carex integra, $C A A T=$ Carex athrostachya, $C A F E=$ Carex festivella, $C A N E=$ Carex nebraskensis. 
hours. The weight of each segment was recorded in grams.

The percentage weight removed in relation to percentage height removed was calculated for each sample by species and year. The data were then subjected to regression analysis to determine the correlation between average percent height removed and average percent weight removed. Then, $\mathrm{n}^{\text {th }}$ order regression analysis was used to generate lines of best fit and the equation was used to produce percentage weight removed by stubble height tables.

\section{Results and Discussion}

A close correlation was found between percentage height removed and percentage weight removed in all four sedge species. The height-weight relationships of both slenderbeak sedge and smoothbeak sedge were expressed by the exponential $y=a b^{x}$, and the correlation coefficient of the curvilinear line for both species was 0.94 . The exponential curve $y=a x b$ best expressed the height-weight relationships of ovalhead sedge and Nebraska sedge. The correlation coefficient of the curvilinear line was 0.98 for ovalhead sedge and 0.95 for Nebraska sedge. In addition to individual differences between species expressed by different exponentials for lines of best fit, the form of $n^{\text {th }}$ order regression lines for each species reflected individual species differences. The individual species differences occurring in Carex species (Fig. 1) are similar to that of grasses as found by Lommasson and Jensen (1943). As in grasses, most of the weight of sedges is in the lower few inches of the plant.

Consecutive clippings in early September of 1969, 1970, and 1971 demonstrated slight yearly variations in the height-weight of slenderbeak sedge (Fig. 2). Exponential correlation coefficients of $0.94,0.96$, and 0.95 were obtained. These yearly variations were also observed in grasses by Heady (1950). As the same plants were clipped each year at the soil surface, the slope of the exponential line remained much the same.

Percentage of weight removed tables were generated from the $\mathrm{n}^{\text {th }}$ order regression equation of each species (Fig. 1). These tables provide a reliable estimate of the actual percentage weight removed at $1 / 2$-inch stubble height increments in relation to average ungrazed plant heights (Tables 1 to 4 ). These tables reflect species differences, the concentration of weight in the lower few inches of the plant, and demonstrate the effect of height on weight distribution within species. This effect is expressed by stubble height changes when percentage weight removed is constant in relation to different ungrazed plant heights. By establishing tables that reflect height classes and their effect on weight distribution, variations between years and sites can be reduced. Heady (1950) recognized this effect of plant height on the growth form of bunchgrass between years and sites and recommended establishing separate tables for
A THREE-YEAR HEIGHT-WEIGHT COMPARISON OF

\section{Carex athrostachya}

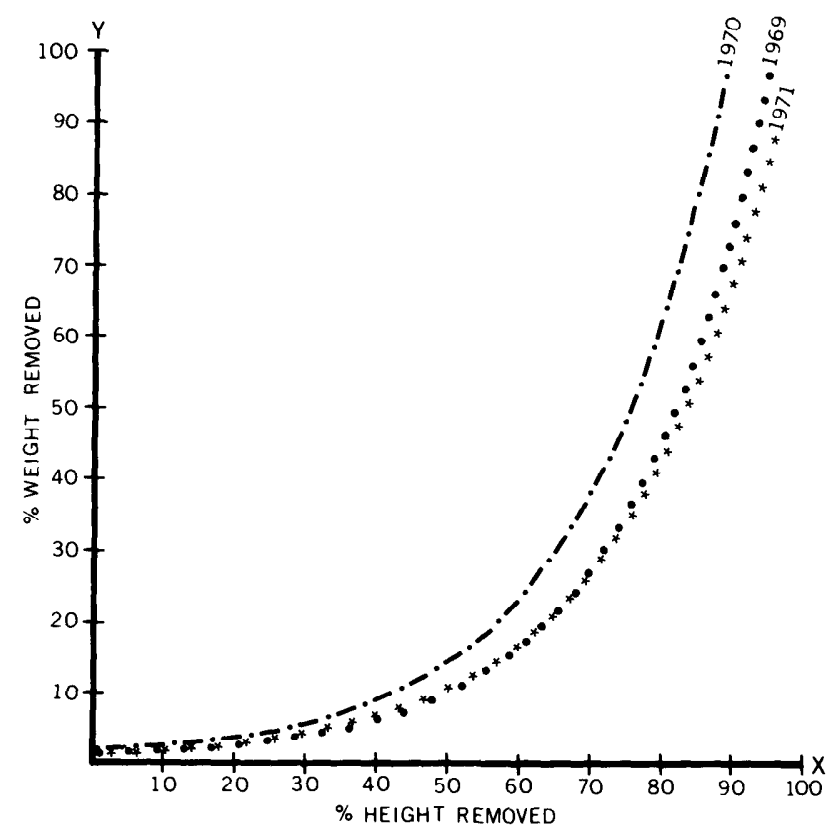

Fig. 2. A 3-year comparison of height-weight curves of Carex athrostachya.

different height classes.

Comparing Region 3-inch stubble height definition used by Region 5 of the Forest Service for a grazed plot to the percent of weight removed tables for smoothbeak sedge, slenderbeak sedge, ovalhead sedge, and Nebraska sedge shows a wide range of utilization values between species and within species based upon height classes. With an ungrazed plant height variation between 12 and 24 inches, a grazed plot could mean anything from 36 to $62 \%$ utilization for slenderbeak sedge, 54 to $75 \%$ for ovalhead sedge, or 54 to $75 \%$ for Nebraska sedge (Tables 2 to 4).

\section{Management Implications}

\section{Use vs Condition}

Livestock use on the Summit Allotment over the past 20 years has ranged from 800 to 1,000 animal unit months. Cattle numbers have fluctuated from 350 to 450 head with a July 1 to September 15 season of use and a 15-day fluctuation at either the beginning or the end of the season. Table 1. Percent of weight removed by stubble height and ungrazed plant height classes from smoothbeak sedge (Carex integra) on Nobe Young Meadow,
Summit Allotment, Sequoia National Forest, average of 1969,1970 , and 1971 data.

\begin{tabular}{|c|c|c|c|c|c|c|c|c|c|c|c|c|c|c|c|c|c|c|c|c|}
\hline \multirow{2}{*}{$\begin{array}{c}\text { Height of } \\
\text { ungrazed } \\
\text { plants (inches) }\end{array}$} & \multicolumn{15}{|c|}{ Stubble heights (inches) } & \multirow[b]{2}{*}{8} & \multirow[b]{2}{*}{$81 / 2$} & \multirow[b]{2}{*}{9} & \multirow[b]{2}{*}{$91 / 2$} & \multirow[b]{2}{*}{10} \\
\hline & $1 / 2$ & 1 & $11 / 2$ & 2 & $21 / 2$ & 3 & $31 / 2$ & 4 & $41 / 2$ & 5 & $51 / 2$ & 6 & $61 / 2$ & 7 & $71 / 2$ & & & & & \\
\hline 1 & 33 & 0 & & & & & & & & & & & & & & & & & & \\
\hline $\begin{array}{l}2 \\
3\end{array}$ & $\begin{array}{l}66 \\
78\end{array}$ & $\begin{array}{l}33 \\
54\end{array}$ & $\begin{array}{l}12 \\
33\end{array}$ & $\begin{array}{r}0 \\
18\end{array}$ & 8 & 0 & & & & & & & & & & & & & & \\
\hline 4 & 84 & 66 & 48 & 33 & 21 & 16 & 6 & 0 & & & & & & & & & & & & \\
\hline 5 & 87 & 73 & 59 & 40 & 33 & 23 & 15 & 10 & 5 & 0 & & & & & & & & & & \\
\hline 6 & 90 & 78 & 66 & 54 & 43 & 33 & 25 & 18 & 12 & 8 & 4 & 0 & & & & & & & & \\
\hline 7 & 91 & 81 & 71 & 61 & 51 & 41 & 33 & 26 & 20 & 15 & 10 & 7 & 4 & 0 & & & & & & \\
\hline 8 & 92 & 84 & 75 & 66 & 57 & 48 & 40 & 33 & 27 & 21 & 19 & 12 & 9 & 6 & 3 & 0 & & & & \\
\hline 9 & 93 & 86 & 78 & 70 & 62 & 54 & 47 & 40 & 33 & 27 & 22 & 18 & 14 & 11 & 8 & 5 & 3 & c & & \\
\hline 10 & 94 & 87 & 80 & 73 & 66 & 59 & 52 & 45 & 39 & 33 & 28 & 23 & 19 & 15 & 12 & 10 & 7 & 5 & 3 & 0 \\
\hline
\end{tabular}


Table 2. Percent of weight removed by stubble height and ungrazed plant height classes from slenderbeak sedge (Carex athrostachya) on Packsaddle Meadow, Summit Allotment, Sequoia National Forest, average of 1969, 1970, and 1971 data.

\begin{tabular}{|c|c|c|c|c|c|c|c|c|c|c|c|c|c|c|c|c|c|c|c|c|c|c|c|c|c|c|c|c|c|c|c|c|}
\hline \multirow{2}{*}{$\begin{array}{c}\text { Height of } \\
\text { ungrazed } \\
\text { plants (inches) }\end{array}$} & \multicolumn{32}{|c|}{ Stubble heights (inches) } \\
\hline & $1 / 2$ & & $11 / 2$ & & $21 / 2$ & & $31 / 2$ & & $41 / 2$ & 5 & 6 & 7 & 8 & 9 & 10 & 11 & 12 & 13 & 14 & 15 & 16 & 17 & 18 & 19 & 20 & 21 & 22 & 23 & 24 & 25 & 26 & 27 \\
\hline 2 & 36 & 12 & 3 & 0 & & & & & & & & & & & & & & & & & & & & & & & & & & & & \\
\hline 3 & 52 & 25 & 12 & 5 & 1 & 0 & & & & & & & & & & & & & & & & & & & & & & & & & & \\
\hline 4 & 62 & 36 & 21 & 12 & 6 & 3 & 1 & 0 & & & & & & & & & & & & & & & & & & & & & & & & \\
\hline 5 & 69 & 45 & 29 & 19 & 12 & 7 & 4 & 2 & 0 & 0 & & & & & & & & & & & & & & & & & & & & & & \\
\hline 6 & 74 & 52 & 36 & 25 & 17 & 12 & 8 & 5 & 3 & 1 & 0 & & & & & & & & & & & & & & & & & & & & & \\
\hline 7 & 78 & 58 & 43 & 31 & 23 & 16 & 12 & 8 & 6 & 4 & 1 & 0 & & & & & & & & & & & & & & & & & & & & \\
\hline 8 & 81 & 62 & 48 & 36 & 28 & 21 & 16 & 12 & 9 & 6 & 3 & 1 & 0 & & & & & & & & & & & & & & & & & & & \\
\hline 9 & 83 & 66 & 52 & 41 & 32 & 25 & 20 & 15 & 12 & 9 & 5 & 2 & 0 & 0 & & & & & & & & & & & & & & & & & & \\
\hline 10 & 85 & 69 & 56 & 45 & 36 & 29 & 23 & 19 & 15 & 12 & 7 & 4 & 2 & 0 & 0 & & & & & & & & & & & & & & & & & \\
\hline 11 & 86 & 72 & 59 & 49 & 40 & 33 & 27 & 22 & 18 & 15 & 10 & 6 & 3 & 1 & 0 & 0 & & & & & & & & & & & & & & & & \\
\hline 12 & 88 & 74 & 62 & 52 & 44 & 36 & 30 & 25 & 21 & 17 & 12 & 8 & 5 & 3 & 1 & 0 & 0 & & & & & & & & & & & & & & & \\
\hline 13 & 89 & 76 & 65 & 55 & 47 & 40 & 33 & 28 & 24 & 20 & 14 & 10 & 7 & 4 & 2 & 1 & 0 & 0 & & & & & & & & & & & & & & \\
\hline 14 & 90 & 78 & 67 & 58 & 50 & 43 & 36 & 31 & 27 & 23 & 16 & 12 & 8 & 6 & 4 & 2 & 1 & 0 & 0 & & & & & & & & & & & & & \\
\hline 15 & 91 & 79 & 69 & 60 & 52 & 45 & 39 & 34 & 29 & 25 & 19 & 14 & 10 & 7 & 5 & 3 & 2 & 1 & 0 & 0 & & & & & & & & & & & & \\
\hline 16 & 91 & 81 & 71 & 62 & 55 & 48 & 42 & 36 & 32 & 28 & 21 & 16 & 12 & 9 & 6 & 4 & 3 & 1 & 1 & 0 & 0 & & & & & & & & & & & \\
\hline 17 & 92 & 82 & 73 & 64 & 57 & 50 & 44 & 39 & 34 & 30 & 23 & 18 & 14 & 10 & 8 & 6 & 4 & 2 & 1 & 0 & 0 & 0 & & & & & & & & & & \\
\hline 18 & 93 & 83 & 74 & 66 & 59 & 52 & 46 & 41 & 36 & 32 & 25 & 20 & 15 & 12 & 9 & 7 & 5 & 3 & 2 & 1 & 0 & 0 & 0 & & & & & & & & & \\
\hline 19 & 93 & 84 & 75 & 68 & 61 & 54 & 48 & 43 & 39 & 34 & 27 & 22 & 17 & 13 & 10 & 8 & 6 & 4 & 3 & 2 & 1 & 0 & 0 & 0 & & & & & & & & \\
\hline 20 & 94 & 85 & 77 & 69 & 62 & 56 & 50 & 45 & 41 & 36 & 29 & 23 & 19 & 15 & 12 & 9 & 7 & 6 & 4 & 3 & 2 & 1 & 0 & 0 & 0 & & & & & & & \\
\hline 21 & 94 & 86 & 78 & 70 & 64 & 58 & 52 & 47 & 43 & 38 & 31 & 25 & 20 & 16 & 13 & 11 & 8 & 7 & 5 & 4 & 2 & 2 & 1 & 0 & 0 & 0 & & & & & & \\
\hline 22 & 95 & 86 & 79 & 72 & 65 & 59 & 54 & 49 & 44 & 40 & 33 & 27 & 22 & 18 & 15 & 12 & 10 & 8 & 6 & 5 & 3 & 2 & 1 & 1 & 0 & 0 & 0 & & & & & \\
\hline 23 & 95 & 87 & 80 & 73 & 67 & 61 & 55 & 51 & 46 & 42 & 35 & 29 & 24 & 19 & 16 & 13 & 11 & 9 & 7 & 5 & 4 & 3 & 2 & 1 & 1 & 0 & 0 & 0 & & & & \\
\hline 24 & 95 & 88 & 81 & 74 & 68 & 62 & 57 & 52 & 48 & 44 & 36 & 30 & 25 & 21 & 17 & 14 & 12 & 10 & 8 & 6 & 5 & 4 & 3 & 2 & 1 & 1 & 0 & 0 & 0 & & & \\
\hline 25 & 96 & 88 & 81 & 75 & 69 & 64 & 58 & 54 & 49 & 45 & 38 & 32 & 27 & 22 & 19 & 16 & 13 & 11 & 9 & 7 & 6 & 5 & 4 & 3 & 2 & 1 & 0 & 0 & 0 & 0 & & \\
\hline 26 & 96 & 89 & 82 & 76 & 70 & 65 & 60 & 55 & 51 & 47 & 40 & 33 & 28 & 24 & 20 & 17 & 14 & 12 & 10 & 8 & 7 & 5 & 4 & 3 & 2 & 2 & 1 & 0 & 0 & 0 & 0 & \\
\hline 27 & 96 & 89 & 83 & 77 & 71 & 66 & 61 & 56 & 52 & 48 & 41 & 35 & 30 & 25 & 21 & 18 & 10 & 13 & 11 & 9 & 8 & 6 & 5 & 4 & 3 & 2 & 1 & 1 & 0 & 0 & 0 & 0 \\
\hline
\end{tabular}

Forage utilization based upon the Region 5 grazed-plot method indicates that the stocking level over the past 10 years has exceeded the level considered necessary for maintenance or improvement of the range resource. However, range condition analysis by toe-point transect shows a $26 \%$ increase in satisfactory condition. After 20 years of grazing, $94 \%$ of the range was in satisfactory condition. Therefore, it is apparent that high levels of forage utilization as measured by the grazed-plot method has not resulted in declining range condition.
Comparing 5 years' utilization measurements taken at the end of the grazing season with the percentage weight removed table for Nebraska sedge reveals that percentage of allowed use measurements are more a function of the grazed plot definition than of livestock grazing. By definition, a grazed plot recognizes utilization in relation to a single height measurement. This shortcoming does not provide adequate information to relate utilization to range condition. Percentage of allowed use is the relationship between defined grazed plots and the allowed use

Table 3. Percent of weight removed by stubble height and ungrazed plant height classes from ovalhead sedge (Carex festivella) on Redwood Meadow, Summit Allotment, Sequoia National Forest, 1973.

\begin{tabular}{|c|c|c|c|c|c|c|c|c|c|c|c|c|c|c|c|c|c|c|c|c|c|c|c|c|c|c|c|c|c|c|c|c|}
\hline \multirow{2}{*}{$\begin{array}{c}\text { Height of } \\
\text { ungrazed } \\
\text { plants (inches) }\end{array}$} & \multicolumn{32}{|c|}{ Stubble heights (inches) } \\
\hline & $1 / 2$ & & $1 \frac{1 / 2}{2}$ & & $2^{1 / 2}$ & & $31 / 2$ & & $4 \frac{1}{2}$ & & $51 / 2$ & 6 & 7 & 8 & 9 & 10 & 11 & 12 & 13 & 14 & 15 & 16 & 17 & 18 & 19 & 20 & 21 & 22 & 23 & 24 & 25 & 26 \\
\hline 4 & 75 & 54 & 37 & 23 & 13 & 6 & 3 & 0 & & & & & & & & & & & & & & & & & & & & & & & & \\
\hline 5 & 80 & 62 & 47 & 34 & 23 & 15 & 8 & 4 & 2 & 0 & & & & & & & & & & & & & & & & & & & & & & \\
\hline 6 & 83 & 68 & 54 & 42 & 32 & 23 & 16 & 10 & 6 & 3 & 2 & 0 & & & & & & & & & & & & & & & & & & & & \\
\hline 7 & 85 & 72 & 60 & 49 & 39 & 31 & 23 & 17 & 12 & 8 & 5 & 3 & 0 & & & & & & & & & & & & & & & & & & & \\
\hline 8 & 87 & 75 & 64 & 54 & 40 & 37 & 30 & 23 & 18 & 13 & 9 & 6 & 3 & 0 & & & & & & & & & & & & & & & & & & \\
\hline 9 & 88 & 78 & 68 & 59 & 50 & 42 & 35 & 29 & 23 & 18 & 14 & 10 & 5 & 2 & 0 & & & & & & & & & & & & & & & & & \\
\hline 10 & 89 & 80 & 71 & 62 & 54 & 47 & 40 & 34 & 28 & 23 & 19 & 15 & 8 & 4 & 2 & 0 & & & & & & & & & & & & & & & & \\
\hline 11 & 90 & 81 & 73 & 65 & 58 & 51 & 44 & 38 & 33 & 28 & 23 & 19 & 12 & 7 & 4 & 2 & 0 & & & & & & & & & & & & & & & \\
\hline 12 & 91 & 83 & 75 & 68 & 61 & 54 & 48 & 42 & 37 & 32 & 27 & 23 & 16 & 10 & 6 & 3 & 2 & 0 & & & & & & & & & & & & & & \\
\hline 13 & 91 & 84 & 77 & 70 & 63 & 57 & 51 & 49 & 41 & 36 & 31 & 27 & 20 & 14 & 9 & 5 & 3 & 2 & 0 & & & & & & & & & & & & & \\
\hline 14 & 92 & 85 & 78 & 72 & 66 & 60 & 54 & 49 & 44 & 39 & 35 & 31 & 23 & 17 & 12 & 8 & 5 & 3 & 2 & 0 & & & & & & & & & & & & \\
\hline 15 & 92 & 86 & 80 & 74 & 68 & 62 & 57 & 52 & 47 & 42 & 38 & 34 & 27 & 20 & 15 & 10 & 7 & 4 & 3 & 2 & 0 & & & & & & & & & & & \\
\hline 16 & 93 & 87 & 81 & 75 & 70 & 64 & 59 & 54 & 50 & 45 & 41 & 37 & 30 & 23 & 18 & 13 & 9 & 6 & 4 & 3 & 2 & 0 & & & & & & & & & & \\
\hline 17 & 93 & 87 & 82 & 76 & 71 & 66 & 61 & 57 & 52 & 48 & 44 & 40 & 33 & 26 & 20 & 16 & 11 & 8 & 5 & 4 & 2 & 2 & 0 & & & & & & & & & \\
\hline 18 & 94 & 88 & 83 & 78 & 73 & 68 & 63 & 59 & 54 & 50 & 46 & 42 & 35 & 29 & 23 & 18 & 14 & 10 & 7 & 5 & 3 & 2 & 2 & 0 & & & & & & & & \\
\hline 19 & 94 & 89 & 84 & 79 & 74 & 69 & 65 & 60 & 56 & 52 & 48 & 45 & 38 & 32 & 26 & 21 & 16 & 12 & 9 & 7 & 5 & 3 & 2 & 2 & 0 & & & & & & & \\
\hline 20 & 94 & 89 & 84 & 80 & 75 & 71 & 66 & 62 & 58 & 54 & 51 & 47 & 40 & 34 & 28 & 23 & 19 & 15 & 11 & 8 & 6 & 4 & 3 & 2 & 2 & 0 & & & & & & \\
\hline 21 & 94 & 90 & 85 & 81 & 76 & 72 & 68 & 64 & 60 & 56 & 52 & 49 & 42 & 36 & 31 & 26 & 21 & 17 & 13 & 10 & 8 & 6 & 4 & 3 & 2 & 2 & 0 & & & & & \\
\hline 22 & 95 & 90 & 86 & 81 & 77 & 73 & 69 & 65 & 61 & 58 & 54 & 51 & 44 & 38 & 33 & 28 & 23 & 19 & 15 & 12 & 9 & 7 & 5 & 4 & 3 & 2 & 2 & 0 & & & & \\
\hline 23 & 95 & 90 & 86 & 82 & 78 & 74 & 70 & 67 & 63 & 59 & 56 & 53 & 46 & 40 & 35 & 30 & 25 & 21 & 17 & 14 & 11 & 9 & 6 & 5 & 3 & 3 & 2 & 2 & 0 & & & \\
\hline 24 & 95 & 91 & 87 & 83 & 79 & 75 & 71 & 68 & 64 & 61 & 58 & 54 & 48 & 42 & 37 & 32 & 27 & 23 & 19 & 16 & 13 & 10 & 8 & 6 & 4 & 3 & 3 & 2 & 2 & 0 & & \\
\hline 25 & 95 & 91 & 87 & 83 & 80 & 76 & 72 & 69 & 65 & 62 & 59 & 56 & 50 & 44 & 39 & 34 & 29 & 25 & 21 & 18 & 15 & 12 & 9 & 7 & 6 & 4 & 3 & 3 & 2 & 2 & 0 & \\
\hline 26 & 95 & 91 & 88 & 84 & 80 & 77 & 73 & 70 & 67 & 63 & 60 & 57 & 51 & 46 & 41 & 36 & 31 & 27 & 23 & 20 & 16 & 14 & 11 & 9 & 7 & 5 & 4 & 3 & 2 & 2 & 2 & 0 \\
\hline
\end{tabular}


Table 4. Percent of weight removed by stubble height and ungrazed plant classes from Nebraska sedge (Carex nebraskensis) on Redwood Meadow, Summit Allotment, Sequoia National Forest, in 1973.

\begin{tabular}{|c|c|c|c|c|c|c|c|c|c|c|c|c|c|c|c|c|c|c|c|c|c|c|c|c|c|c|c|c|c|c|c|c|}
\hline \multirow{2}{*}{$\begin{array}{c}\text { Height of } \\
\text { ungrazed } \\
\text { plants (inches) }\end{array}$} & \multicolumn{32}{|c|}{ Stubble height (inches) } \\
\hline & $1 / 2$ & 1 & $1 \frac{1}{2}$ & & $2 \frac{1}{2}$ & 3 & $31 / 2$ & 4 & $41 / 2$ & & $51 / 2$ & & $61 / 2$ & 7 & 8 & 9 & 10 & 11 & 12 & 13 & 14 & 15 & 16 & 17 & 18 & 19 & 20 & 21 & 22 & 23 & 24 & 25 \\
\hline 4 & 75 & 54 & 37 & 23 & 12 & 5 & 1 & 0 & & & & & & & & & & & & & & & & & & & & & & & & \\
\hline 5 & 79 & 62 & 47 & 34 & 23 & 14 & 8 & 3 & 1 & 0 & & & & & & & & & & & & & & & & & & & & & & \\
\hline 6 & 83 & 68 & 54 & 42 & 32 & 23 & 16 & 10 & 5 & 2 & 1 & 0 & & & & & & & & & & & & & & & & & & & & \\
\hline 7 & 85 & 72 & 60 & 49 & 39 & 31 & 23 & 17 & 11 & 7 & 4 & 2 & 1 & 0 & & & & & & & & & & & & & & & & & & \\
\hline 8 & 86 & 75 & 64 & 54 & 45 & 37 & 30 & 23 & 17 & 12 & 8 & 5 & 3 & 1 & 0 & & & & & & & & & & & & & & & & & \\
\hline 9 & 88 & 77 & 68 & 59 & 50 & 42 & 35 & 29 & 23 & 18 & 14 & 10 & 7 & 4 & 1 & 0 & & & & & & & & & & & & & & & & \\
\hline 10 & 89 & 79 & 71 & 62 & 54 & 47 & 40 & 34 & 28 & 23 & 18 & 14 & 11 & 8 & 3 & 1 & 0 & & & & & & & & & & & & & & & \\
\hline 11 & 90 & 81 & 73 & 65 & 58 & 51 & 45 & 39 & 33 & 28 & 23 & 19 & 15 & 12 & 6 & 3 & 1 & 0 & & & & & & & & & & & & & & \\
\hline 12 & 91 & 83 & 75 & 68 & 61 & 54 & 48 & 42 & 37 & 32 & 27 & 23 & 19 & 16 & 10 & 5 & 2 & 1 & 0 & & & & & & & & & & & & & \\
\hline 13 & 91 & 84 & 77 & 70 & 63 & 57 & 51 & 46 & 41 & 36 & 31 & 27 & 23 & 20 & 13 & 8 & 4 & 2 & 1 & 0 & & & & & & & & & & & & \\
\hline 14 & 92 & 85 & 78 & 72 & 66 & 60 & 54 & 49 & 44 & 39 & 35 & 31 & 27 & 23 & 17 & 11 & 7 & 4 & 2 & 1 & 0 & & & & & & & & & & & \\
\hline 15 & 92 & 86 & 79 & 73 & 68 & 62 & 57 & 52 & 47 & 42 & 38 & 34 & 30 & 27 & 20 & 14 & 10 & 6 & 3 & 1 & 1 & 0 & & & & & & & & & & \\
\hline 16 & 93 & 86 & 81 & 75 & 69 & 64 & 59 & 54 & 50 & 45 & 41 & 37 & 33 & 30 & 23 & 17 & 12 & 8 & 5 & 3 & 1 & 1 & 0 & & & & & & & & & \\
\hline 17 & 93 & 87 & 82 & 76 & 71 & 66 & 61 & 57 & 52 & 48 & 44 & 40 & 36 & 33 & 26 & 20 & 15 & 11 & 7 & 5 & 2 & 1 & 1 & 0 & & & & & & & & \\
\hline 18 & 93 & 88 & 83 & 77 & 72 & 68 & 63 & 59 & 54 & 50 & 46 & 42 & 39 & 35 & 29 & 23 & 18 & 14 & 10 & 7 & 4 & 2 & 1 & 1 & 0 & & & & & & & \\
\hline 19 & 94 & 88 & 83 & 79 & 74 & 69 & 65 & 61 & 56 & 52 & 49 & 45 & 41 & 38 & 32 & 26 & 21 & 16 & 12 & 9 & 6 & 4 & 2 & 1 & 1 & 0 & & & & & & \\
\hline 20 & 94 & 89 & 84 & 79 & 75 & 71 & 66 & 62 & 58 & 54 & 51 & 47 & 44 & 40 & 34 & 28 & 23 & 18 & 14 & 11 & 8 & 5 & 3 & 2 & 1 & 1 & 0 & & & & & \\
\hline 21 & 94 & 89 & 85 & 80 & 76 & 72 & 68 & 64 & 60 & 56 & 53 & 49 & 46 & 42 & 36 & 31 & 26 & 21 & 17 & 13 & 10 & 7 & 5 & 3 & 2 & 1 & 1 & 0 & & & & \\
\hline 22 & 94 & 90 & 85 & 81 & 77 & 73 & 69 & 65 & 61 & 58 & 54 & 51 & 48 & 45 & 39 & 33 & 28 & 23 & 19 & 15 & 12 & 9 & 6 & 4 & 3 & 1 & 1 & 1 & 0 & & & \\
\hline 23 & 94 & 90 & 86 & 82 & 78 & 74 & 70 & 66 & 63 & 59 & 56 & 53 & 50 & 46 & 41 & 35 & 30 & 25 & 21 & 17 & 14 & 11 & 8 & 6 & 4 & 2 & 1 & 1 & 1 & 0 & & \\
\hline 24 & 95 & 91 & 86 & 83 & 79 & 75 & 71 & 68 & 64 & 61 & 58 & 54 & 51 & 48 & 42 & 37 & 32 & 27 & 23 & 19 & 16 & 12 & 10 & 7 & 5 & 3 & 2 & 1 & 1 & 1 & 0 & \\
\hline 25 & 95 & 91 & 87 & 83 & 79 & 76 & 72 & 69 & 65 & 62 & 59 & 56 & 53 & 50 & 44 & 39 & 34 & 29 & 25 & 21 & 18 & 14 & 11 & 9 & 7 & 5 & 3 & 2 & 1 & 1 & 1 & 0 \\
\hline
\end{tabular}

factors for wet meadows. This relationship does not accurately reflect actual forage utilization.

\section{Suggested Changes in Method}

Rather than define a grazed plot as a 3-inch diameter ring with a 3-inch maximum stubble height (U.S. Dep. Agr., Forest Serv., 1969), we suggest the following: Systematically toepoint 100 vegetative and/or reproductive culms of a single key species in a key area. Instead of determining whether the species is grazed or ungrazed according to a defined stubble height, measure the length of the culm to the nearest $1 / 2$-inch. The percentage weight removed can then be determined from the height-weight table according to height class. The current height class can be determined by measuring 15 ungrazed plants in the key area. The percentage weight removed or utilization can then be related to allowed use by assuming the present allowed use factors represent percentages of weight which can be removed for each condition class. This assumption is in accordance with the knowledge of plant requirements used in establishment of the allowed use factors. Percentage of allowed use is then shown as actual percentage weight removed compared to allowed percentage weight removed.

The key species selected for utilization measurements under this system on the Summit Allotment is Nebraska sedge. This species was selected because of its ecological status, forage value, palatability, and because it represents $36 \%$ cover of all primary and secondary vegetation occurring in wet mountain meadows of the Summit Allotment, as computed from recent toe-point analyses. The vegetative characteristics of this species as compared to the characteristics of the other three species studied facilitate positive identification after grazing. As more experience is gained using this method, allowed percentages of weight removed can be determined for each species and an even more accurate picture of utilization obtained. Proper grazing use will then be achieved and the range resource managed effectively.

\section{Literature Cited}

Charlton, M. 1968. Grazed plant utilization method. J. Range Manage. 21:334-335

Gierison, R. K. 1967. An adaptation of the grazed plant method for estimating utilization of Thurber fescue (Festuca thurberi). J. Range Manage. 20: 108-111.

Heady, H. F. 1950. Studies on bluebunch wheatgrass in Montana and heightweight relationships of certain range grasses. Ecol. Monogr. 20:55-81.

Hurd, R. M., and N. A. Kissinger, Jr. 1953. Estimating utilization of Idaho fescue (Festuca idahoensis) on cattle range by percent of plants grazed. U.S. Forest Service, Rocky Mountain Forest and Range Exp. Sta. Paper 12. 5 p.

Lommasson, T., and C. Jensen. 1943. Determining the utilization of range grasses from height-weight tables. J. Forest. 41:589-593.

Mattox, J. E. 1955. A study of percent-of-plants-grazed method of utilization determination and its application. Montana Agr. Exp. Sta. Circ. 88. 140 p.

Roach, M. E. 1950. Estimating perennial grass utilization on semi-desert cattle ranges by percentage of ungrazed plants. J. Range Manage. 3:182-185.

Springfield, H. W. 1959. Estimating the utilization of crested wheatgrass from counts of grazed plants. U.S. Forest Service, Rocky Mountain Forest and Range Exp. Sta. Res. Note 38.6 p.

Springfield, H. W. 1961. The grazed-plant method for judging the utilization of crested wheatgrass. J. Forest. 59:666-670.

Springfield, H. W., and G. Peterson. 1964. Use of the grazed-plant method for estimating utilization of some range grasses in New Mexico. U.S. Forest Service, Rocky Mountain Forest and Range Exp. Sta. Res. Note R.M. 22. $6 \mathrm{p}$.

U.S. Department of Agriculture, Forest Service. 1968. U.S. Forest Serv. Manual 2200-12.

U.S. Department of Agriculture, Forest Service. 1969. R-5 Range Environmental Analysis Handbook. 2209-21:600-629. 